ORIGINAL PAPER

\title{
COMPARISON BETWEEN IMMUNOHISTOCHEMICAL EXPRESSION OF KI-67 AND MCM-3 IN MAJOR SALIVARY GLAND EPITHELIAL TUMORS IN CHILdREN AND ADOlesCents. Preliminary STUDY
}

\author{
Rafae Zieliński, Jozef Kobos, Anna Zakrzewska
}

Department of Pediatric Otorhinolaryngology, Medical University of Lodz, Lodz, Poland

\begin{abstract}
While Ki-67 expression is frequently used as an indicator of tumor cell proliferation, alternative markers have also been proposed. Possible alternative indicators of proliferation are the minichromosome maintenance (MCM) proteins, whose levels are inversely associated with tumor cell differentiation.

The aim of this preliminary study was to compare the levels of Ki-67 and MCM-3 expression in major salivary gland epithelial tumors in all children and adolescents who underwent surgery in our department in the years 2009-2014.

The histopathological diagnosis of the subjects was reviewed, as well as the expression of $\mathrm{Ki}-67$ and MCM-3 in post-op specimens of the tumors.

The normality of data was checked with the Shapiro-Wilk test. The t test for independent variables or the $\mathrm{U}$ test was used as appropriate to determine statistically significant differences in the expression of Ki-67 and MCM-3. Five cases of pleomorphic adenoma, one of myoepithelioma, one of basal cell adenoma and one of mucoepidermoid carcinoma were identified. Significantly greater MCM-3 than $\mathrm{Ki}-67$ expression was observed in every case. The results of our preliminary study emphasize the need for future research on MCM-3 as a sensitive proliferation marker, providing an alternative to $\mathrm{Ki}-67$, in cases of various major salivary gland epithelial tumors in children and adolescents.
\end{abstract}

Key words: salivary, tumor, children, MCM-3, Ki-67.

\section{Introduction}

Epithelial tumors of the major salivary glands are very rare in children. However, they mostly affect the parotid gland and are more common in those over ten years old, with approximately $70 \%$ occurring between 16 and 20 years of age [1]. Nevertheless the most common epithelial tumors of the major salivary glands in children and adolescents are pleomorphic adenomas (PA) [2]. However, few authors have reported the various pathological characteristics of major salivary gland tumors in children as well as adolescents and adults [3].

The pathological assessment of major salivary gland tumors should be based on an evaluation of histopathological features, and, if necessary, complementary analysis should be used to confirm the diagnosis [4].

Proliferation marker assessment may be also helpful in preparing both the pathological diagnosis and prognosis. $\mathrm{Ki}-67$ is a protein expressed during active phases of the cell mitotic cycle, but is not present in resting cells. Its expression is therefore frequently used as an indicator of proliferation [5]. However, McCallum and Hall suggest that Ki-67 may play an important role in ribosome biosynthesis and not cell proliferation [6]. The levels of expression of other proliferation markers have also been proposed as new diagnostic and prognostic indicators for various tumors [7]. 
The minichromosome maintenance (MCM) proteins include a group of six proteins which, including MCM-3, are considered to play important roles in DNA replication, allowing one-time replication of the genome in each mitotic cell cycle. An evaluation of MCM protein expression levels may also provide an insight into the prognosis of neoplasms, as the proteins are inversely associated with tumor cell differentiation and their levels could be used as indicators of proliferation [8].

Few papers discuss MCM expression; only one addresses MCM-3 expression in salivary gland tumors, and none of these studies is based on a child population [9].

The aim of this preliminary study was to compare the expression of $\mathrm{Ki}-67$ and MCM-3 in major salivary gland epithelial tumors in all children and adolescents treated with surgery in our department in the years 2009-2014.

\section{Material and methods}

The university review board approved the methods of the present study. The authors have complied with the World Medical Association Declaration of Helsinki regarding ethical conduct of research involving human subjects. The study was conducted under the assumption that research findings would be kept anonymous.

The retrospective study was based on an analysis of formalin-fixed, paraffin-embedded tissue blocks of salivary gland tumors collected during surgical treatment procedures in our department in the years 2009-2014. General clinical data including patient age and gender, as well as the gland involved and site of the tumor, were obtained from patient medical documentation.

Delay before initiation of the treatment, data concerning therapy, pathological post-op assessment and clinical trials were recorded in every case.

Formalin-fixed and paraffin-embedded tissue from the above cases were selected for this study. Slides were created from $3 \mu \mathrm{m}$ thick paraffin sections, stained with hematoxylin and eosin, and used for immunohistochemical study. Standard staining with hematoxylin and eosin using EnVision + HRP kits (Dako) was used to confirm the diagnosis in every case of salivary gland tumor. In the immunohistochemical study, the antibody was applied against $\mathrm{Ki}-$ 67 clone MM1 (dilution 1: 100, Leica Novocastra Laboratories) and MCM-3 clone 101 (dilution $1: 50$, Dako). The antibody was immunostained by antigen unmasking (high temperature/target retrieval solution, $\mathrm{pH}$ 9.0) and incubated for 60 minutes at room temperature. The epithelial layer of normal oral mucosa that had previously demonstrated immunostaining of both markers was used as a positive control.
The cell counting was performed without referral to clinical information or pathological diagnosis. MultiScan Base ver. 8.09 by Computer Scanning Systems was used for image capture and analysis. The cells in each sample were counted in ten microscopic fields, which showed more intense staining. Only clearly definable nuclei with heavy staining were identified as positive.

The acquired data were then analyzed with basic statistics. The mean and median numbers of positive tumor cells out of 1000 tumor cells at high magnification $(400 \times)$ and standard deviation value were computed for each marker in every studied case.

The Shapiro-Wilk test was used to determine whether data concerning the expression of Ki-67 and MCM-3 were normally distributed. Based on the result, statistically significant differences in the expression of Ki-67 and MCM-3 were identified using Student's $\mathrm{t}$ test for independent variables for data following a normal distribution, and the Mann-Whitney $\mathrm{U}$ test for data that did not.

\section{Results}

Eight cases of major salivary gland epithelial tumors were operated on in the years 2009-2014 in our department. There were five cases of pleomorphic adenoma, one case of myoepithelioma, one case of basal cell adenoma and one case of mucoepidermoid carcinoma.

The group comprised 5 boys and 3 girls aged from 7 years 2 months to 17 years 11 months (mean -14 years 2 months; SD -3 years 8 months, Table I). Mean time of delay before initiation of the treatment was $10.7 \pm 5.6$ months (range: $4-20$ months).

In cases of pleomorphic adenoma, myoepithelioma or basal cell adenoma of the parotid gland or submandibular gland, superficial parotidectomy or submandibular gland excision was introduced respectively. In the case of a boy with mucoepidermoid carcinoma, total parotidectomy with facial nerve preservation was introduced. No postoperative complications were observed, either early or later on, including facial nerve weakness or paresis (stage I of facial nerve function according to House-Brackmann), Frey syndrome, lingual or hypoglossal nerve malfunction, bleeding or complicated wound healing.

All pathological diagnoses were based on both hematoxylin and eosin-stained tumor section analysis and assessment of immunohistochemical staining results. In one extremely difficult case, myoepithelioma of the submandibular gland, a pathological "second opinion" was necessary to prepare the final diagnosis. In all of the cases, pathological examination of post-op specimens confirmed the surgical excisions to be complete.

All patients were observed on a regular basis during monthly ambulatory visits. During the one-year ob- 
servation period following surgery, neither clinical examination nor control ultrasonography revealed any signs of tumor recurrence in any studied case.

Similarly, no lymphatic or distant metastases were found in the case of mucoepidermoid carcinoma.

The levels of Ki-67 and MCM-3 expression were assessed in every pathological post-op specimen. Both Ki-67 and MCM-3 expression were present in all the studied tumors.

The results also revealed significantly stronger expression of MCM-3 than Ki-67 in every studied case (Table I, Fig. 1).

\section{Discussion}

Salivary gland epithelial tumors constitute about $3 \%$ of all tumors of the head and neck area and only $5 \%$ of these tumors occur in children and adolescents [10]. It is suggested that in the pediatric population, like in adults, the parotid gland is the most common site involved by pleomorphic adenoma. When a tumor is situated in the submandibular gland it is also mostly a benign lesion, which is not in agreement with studies on adults $[2,11,12]$.

The methods of operational treatment of epithelial salivary gland tumors in children and adolescents do not differ from those in adults and include total or partial removal of the gland along with the tumor and possibly lymphatic operations in case of malignancies. Because of low grade histology, in most cases of major salivary gland malignant epithelial tumors in children and adolescents, elective neck dissections are not necessary. If possible, function of the facial nerve and its branches should always be preserved [12, 13].

In postoperative salivary gland tumor diagnosis, a combination of pathological analysis of hematoxylin and eosin-stained sections and immunohistochemical staining is thought to be the gold standard. Nevertheless, a pathologist often faces a challenge in

Table I. General clinical data, mean and median numbers of cells which showed heavy staining for both Ki-67 and MCM-3 out of 1000 tumor cells at high magnification $(400 \times)$ counted in 10 microscopic fields in studied cases along with Student's t test or Mann-Whitney U test results

\begin{tabular}{|c|c|c|c|c|c|c|}
\hline $\begin{array}{l}\text { NUMBER } \\
\text { OF THE } \\
\text { CASE }\end{array}$ & $\begin{array}{l}\text { Pathological } \\
\text { DiagNOSIS }\end{array}$ & AGE & GENDER & $\begin{array}{l}\text { MEAN AND MEDIAN } \\
\text { NUMBERS OF CELLS WITH } \\
\text { HEAVY STAINING FOR } \\
\text { KI-67 (OF 1000 } \\
\text { COUNTED CELLS) IN } \\
10 \text { MICROSCOPIC FIELDS }\end{array}$ & $\begin{array}{l}\text { MEAN AND MEDIAN } \\
\text { NUMBERS OF CELLS } \\
\text { WITH HEAVY STAINING } \\
\text { FOR MCM-3 (OF } 1000 \\
\text { COUNTED CELLS) IN } \\
10 \text { MICROSCOPIC FIELDS }\end{array}$ & $\begin{array}{c}\text { STUDENT'S } \\
\text { T TEST OR } \\
\text { MANN- } \\
\text { WHITNEY U } \\
\text { TEST RESULT }\end{array}$ \\
\hline 1 & $\begin{array}{l}\text { PA of the left } \\
\text { submandibular } \\
\text { gland }\end{array}$ & $\begin{array}{l}17 \text { years } \\
2 \text { months }\end{array}$ & boy & $\begin{array}{c}\text { Mean } 4 \pm 1.2 \\
\text { Median } 3.5 \pm 1.2\end{array}$ & $\begin{array}{c}\text { Mean } 17.2 \pm 3.9 \\
\text { Median } 16.5 \pm 3.9\end{array}$ & $\mathrm{p}=0.0002$ \\
\hline 2 & $\begin{array}{l}\text { PA of the left } \\
\text { parotid gland }\end{array}$ & 13 years & boy & $\begin{array}{c}\text { Mean } 28.5 \pm 11.2 \\
\text { Median } 25.5 \pm 11.2\end{array}$ & $\begin{array}{c}\text { Mean } 53.8 \pm 11.7 \\
\text { Median } 52.5 \pm 11.7\end{array}$ & $\mathrm{p}=0.0001$ \\
\hline 3 & $\begin{array}{l}\text { PA of the left } \\
\text { parotid gland }\end{array}$ & $\begin{array}{l}17 \text { years } \\
2 \text { months }\end{array}$ & boy & $\begin{array}{c}\text { Mean } 10.1 \pm 3.9 \\
\text { Median } 10.5 \pm 3.9\end{array}$ & $\begin{array}{l}\text { Mean } 17.2 \pm 8.1 \\
\text { Median } 15 \pm 8.1\end{array}$ & $\mathrm{p}=0.0225$ \\
\hline 4 & $\begin{array}{l}\text { PA of the left } \\
\text { parotid gland }\end{array}$ & $\begin{array}{l}12 \text { years } \\
2 \text { months }\end{array}$ & girl & $\begin{array}{l}\text { Mean } 23.5 \pm 11.8 \\
\text { Median } 21 \pm 11.8\end{array}$ & $\begin{array}{l}\text { Mean } 45.3 \pm 11.2 \\
\text { Median } 45 \pm 11.2\end{array}$ & $\mathrm{p}=0.0005$ \\
\hline 5 & $\begin{array}{l}\text { PA of the right } \\
\text { parotid gland }\end{array}$ & $\begin{array}{c}7 \text { years } \\
2 \text { months }\end{array}$ & girl & $\begin{array}{l}\text { Mean } 13.1 \pm 4.9 \\
\text { Median } 12 \pm 4.9\end{array}$ & $\begin{array}{l}\text { Mean } 24.9 \pm 12.7 \\
\text { Median } 23 \pm 12.7\end{array}$ & $\mathrm{p}=0.0376$ \\
\hline 6 & $\begin{array}{c}\text { Myoepithelioma } \\
\text { of the right } \\
\text { submandibular } \\
\text { gland }\end{array}$ & $\begin{array}{l}17 \text { years } \\
11 \text { months }\end{array}$ & boy & $\begin{array}{l}\text { Mean } 14.8 \pm 6.6 \\
\text { Median } 14 \pm 6.6\end{array}$ & $\begin{array}{l}\text { Mean } 30.2 \pm 7.5 \\
\text { Median } 30 \pm 7.5\end{array}$ & $\mathrm{p}=0.0001$ \\
\hline 7 & $\begin{array}{l}\text { Basal cell } \\
\text { adenoma of the } \\
\text { right parotid } \\
\text { gland }\end{array}$ & $\begin{array}{l}16 \text { years } \\
10 \text { months }\end{array}$ & girl & $\begin{array}{l}\text { Mean } 20.7 \pm 4.3 \\
\text { Median } 20 \pm 4.3\end{array}$ & $\begin{array}{l}\text { Mean } 39.2 \pm 11 \\
\text { Median } 38 \pm 11\end{array}$ & $\mathrm{p}=0.0001$ \\
\hline 8 & $\begin{array}{l}\text { Low grade } \\
\text { mucoepidermoid } \\
\text { carcinoma of the } \\
\text { right parotid } \\
\text { gland }\end{array}$ & 12 years & boy & $\begin{array}{l}\text { Mean } 9.4 \pm 3.6 \\
\text { Median } 9 \pm 3.6\end{array}$ & $\begin{array}{l}\text { Mean } 22.5 \pm 11.1 \\
\text { Median } 21 \pm 11.1\end{array}$ & $p=0.0009$ \\
\hline
\end{tabular}



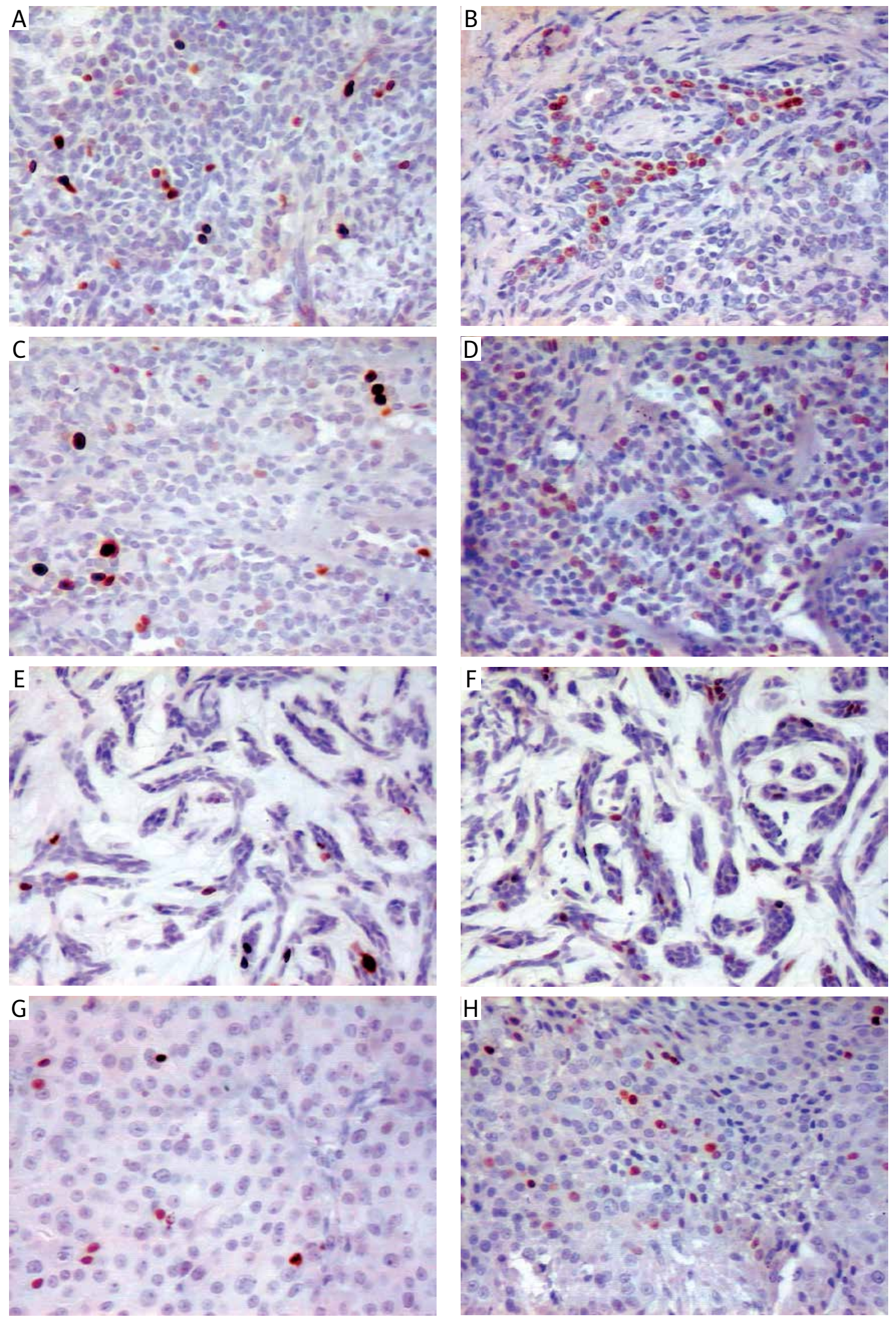

Fig. 1. Case No. 5 (original magnification $200 \times$ ). Pleomorphic adenoma of the parotid gland: expression of Ki-67 (A), expression of MCM-3 (B), Case No. 6 (original magnification $200 \times$ ). Myoepithelioma of the submandibular gland: expression of Ki-67 (C), expression of MCM-3 (D), Case No. 7 (original magnification 200×). Basal cell adenoma of the parotid gland: expression of Ki-67 (E), expression of MCM-3 (F), Case No. 8 (original magnification 200×). Low grade mucoepidermoid carcinoma of the parotid gland: expression of Ki-67 (G), expression of MCM-3 (H) 
the histopathological diagnosis of post-op specimens; thus a second opinion is often needed to make a final diagnosis [14].

Ki-67 expression has been well described in G1, S, G2 and mitotic phases of the cell cycle [7]. The expression of $\mathrm{Ki}-67$ also reaches a peak during G2 and mitotic phases of the cycle [15]. Ki-67 is thus the proliferation marker used to assess various types of tumors [16, 17]. Expression of Ki-67 may also be used as a proliferation marker and prognostic tool in epithelial salivary gland tumor assessment in adults $[18,19]$. Faur suggests that Ki-67 expression may be especially useful in assessment of extremely proliferative forms of salivary gland tumors, both benign and malignant [5].

Nevertheless, De Cruz Perez suggests that Ki-67 expression, as well as that of a few other markers, does not correlate with prognosis of salivary gland tumors in children and adolescents. Unfortunately, while the study presents a qualitative description, it presents no quantitative description of expression [4]. Thus other biomarkers should be considered as alternative proliferation markers in salivary gland epithelial tumors in children and adolescents.

As the degree of DNA replication regulation may be another marker of cell proliferation, MCM protein expression may present an extremely promising tool for the evaluation of cell cycle progression $[20,21]$. The MCM family may act as potential diagnostic and prognostic markers of various tumors [22]. Hua et al. suggest that MCM-3 expression levels are of greater prognostic relevance than histological diagnosis in selected tumors [23]. MCM-3 expression may also be considered as a useful marker for diagnosis of precarcinomatous lesions, e.g. oral dysplasia [24]. The MCM complex may also offer an alternative target for blocking the proliferation of cancerous and precancerous tumor cells and thus also oncological drug development for various tumors, as suggested by Simon et al. [25].

The present study describes the comparison of expression of both $\mathrm{Ki}-67$ and MCM-3 in salivary gland tumors in children and adolescents. Ashkavandi et al. reported similar findings in the assessment of both markers in salivary gland tumors in adults, suggesting that MCM-3 expression may be a more sensitive marker of proliferation than Ki-67 expression in salivary gland pleomorphic adenomas, mucoepidermoid carcinomas, and adenoid cystic carcinomas in adults. They also stated that MCM-3 may be used for differential diagnosis between malignant and benign salivary gland tumors [9].

Our preliminary study based on eight cases proposes that MCM-3 expression could be used as a proliferation marker in epithelial tumors of the major salivary glands in children and adolescents. However, our findings are not sufficient to confirm its value in the diagnosis or prediction of tumor prognosis, its recurrence in benign epithelial tumors, or its recurrence and TNM staging in malignant epithelial lesions of the salivary glands in this age group of patients.

\section{Conclusions}

The results of our preliminary study emphasize the need for future research on MCM-3 as an alternative to $\mathrm{Ki}-67$ and also as a sensitive proliferation marker in cases of various major salivary gland epithelial tumors in children and adolescents.

\section{The authors declare no conflict of interest.}

\section{References}

1. Ribeiro Kde C, Kowalski LP, Saba LM, et al. Epithelial salivary glands neoplasms in children and adolescents: a forty-four-year experience. Med Pediatr Oncol 2002; 39: 594-600.

2. Deng R, Huang X, Hao J, et al. Salivary gland neoplasms in children. J Craniofac Surg 2013; 24: 511-513.

3. Fu H, Wang J, Wang L, et al. Pleomorphic adenoma of the salivary glands in children and adolescents. J Pediatr Surg 2012; 47: 715-719.

4. da Cruz Perez DE, Pires FR, Alves FA, et al. Salivary gland tumors in children and adolescents: a clinicopathologic and immunohistochemical study of fifty-three cases. Int J Pediatr Otorhinolaryngol 2004; 68: 895-902.

5. Faur AC, Sas I, Motoc AG, et al. Ki-67 and p53 immunostaining assessment of proliferative activity in salivary tumors. Rom J Morphol Embryol 2015; 56: 1429-1439.

6. MacCallum DE, Hall PA. The location of $\mathrm{pKi} 67$ in the outer dense fibrillary compartment of the nucleolus points to a role in ribosome biogenesis during the cell division cycle. J Pathol 2000; 190: 537-544.

7. Jonat W, Arnold N. Is the Ki-67 labelling index ready for clinical use? Ann Oncol 2011; 22: 500-502.

8. Carreón-Burciaga RG, González-González R, Molina-Frechero $\mathrm{N}$, et al. Immunoexpression of $\mathrm{Ki}-67, \mathrm{MCM} 2$, and MCM3 in ameloblastoma and ameloblastic carcinoma and their correlations with clinical and histopathological patterns. Dis Markers 2015; 2015: 683087.

9. Ashkavandi ZJ, Najvani AD, Tadbir AA, et al. MCM3 as a novel diagnostic marker in benign and malignant salivary gland tumors. Asian Pac J Cancer Prev 2013; 14: 3479-3482.

10. Varan A, Akyuz C, Atas E, et al. Salivary gland tumors in children: a retrospective clinical review. Pediatr Hematol Oncol 2014; 31: 681-6.

11. Bradley PJ. Frequency and histopathology by site, major pathologies, symptoms and signs of salivary gland neoplasms. Adv Otorhinolaryngol 2016; 78: 9-16.

12. Fang QG, Shi S, Li ZN, et al. Epithelial salivary gland tumors in children: a twenty-five-year experience of 122 patients. Int J Pediatr Otorhinolaryngol 2013; 77: 1252-1254.

13. Aro K, Leivo I, Makitie A. Management of salivary gland malignancies in the pediatric population. Curr Opin Otolaryngol Head Neck Surg 2014; 22: 116-120.

14. Mullin MH, Brierley DJ, Speight PM. Second opinion reporting in head and neck pathology: the pattern of referrals and impact on final diagnosis. Oral Surg Oral Med Oral Pathol Oral Radiol 2015; 119: 656-660.

15. Bagulkar BB, Gawande M, Chaudhary M, et al. XIAP and Ki-67: A Correlation Between Antiapoptotic and Proliferative Marker Expression in Benign and Malignant Tumours of Sali- 
vary Gland: An Immunohistochemical Study. J Clin Diagn Res 2015; 9: EC01-4.

16. Brown DC, Gatter KC. Ki67 protein: the immaculate deception? Histopathology 2002; 40: 2-11.

17. Tadbir AA, Pardis S, Ashkavandi ZJ, et al. Expression of Ki67 and $\mathrm{CD} 105$ as proliferation and angiogenesis markers in salivary gland tumors. Asian Pac J Cancer Prev 2012; 13: 5155 5159.

18. Fonseca FP, de Andrade BA, Rangel AL, et al. Tissue microarray is a reliable method for immunohistochemical analysis of pleomorphic adenoma. Oral Surg Oral Med Oral Pathol Oral Radiol 2014; 117: 81-88.

19. Tauziède-Espariat A, Raffoul J, Sun SR, et al. A bilateral epithelial myoepithelial carcinoma of the parotid gland. Ann Pathol 2015; 35: 489-495.

20. Forsburg SL. Eukaryotic MCM proteins: beyond replication initiation. Microbiol Mol Biol Rev 2004; 68: 109-131.

21. Li J, Deng M, Wei Q, et al. Phosphorylation of MCM3 protein by cyclin $\mathrm{E} /$ cyclin-dependent kinase $2(\mathrm{Cdk} 2)$ regulates its function in cell cycle. J Biol Chem 2011; 286: 39776-39785.

22. Ha SA, Shin SM, Namkoong H, et al. Cancer-associated expression of minichromosome maintenance 3 gene in several human cancers and its involvement in tumorigenesis. Clin Cancer Res 2004; 10: 8386-8395.

23. Hua C, Zhao G, Li Y, et al. Minichromosome Maintenance (MCM) Family as potential diagnostic and prognostic tumor markers for human gliomas. BMC Cancer 2014; 14: 526.

24. Rezvani G, Andisheh-Tadbir A, Ashraf MJ, et al. Evaluation of Minichromosome Maintenance-3 (MCM3) in Oral Squamous Cell Carcinoma. J Dent (Shiraz) 2015; 16: 87-92.

25. Simon NE, Schwacha A. The Mcm2-7 replicative helicase: a promising chemotherapeutic target. Biomed Res Int 2014; 2014: 549719.

\section{Address for correspondence}

Rafał Zieliński

Department of Pediatric Otorhinolaryngology

Medical University of Lodz

Sporna 36/50

91-738 Łódź, Poland

e-mail: rafal.zielinski@umed.lodz.pl 